\title{
The Relationship between International Humanitarian Law and International Human Rights Law in Situations of Armed Conflict
}

\author{
Sir Daniel Bethlehem QC
}

\author{
Keywords \\ International Human Rights Law, International Humanitarian Law, Armed Con- \\ flict
}

\section{Introduction}

Following some framing remarks to place in wider context the discussion that follows on the relationship between international humanitarian law $(I H L)$ and international human rights law $(H R L)$, and the application of the latter in armed conflict, this paper addresses the following: (a) the systemic relationship between IHL and HRL; (b) whether key HRL provisions are amenable to reasonable application in armed conflict, and, if so, whether there are policy considerations that suggest their application as a matter of discretion, even if they are not applicable de jure; and (c) assuming that HRL provisions apply in armed conflict de jure, or ought to be applied as a matter of discretion, the relationship between relevant IHL and HRL provisions. The paper does not address issues concerning the de jure application of HRL in armed conflict. ${ }^{1}$

\footnotetext{
Sir Daniel Bethlehem QC is a barrister in practice at the London Bar, Director of Legal Policy International Limited (LPI) and a Consulting Senior Fellow for Law and Strategy at the International Institute for Strategic Studies. He was the principal Legal Adviser of the UK Foreign \& Commonwealth Office from May 2006 to May 2011. This is a lightly revised version of a paper presented at an American Society of International Law Roundtable on International Law and Security, held in Washington, DC, on 9 December 2011.

${ }^{1}$ On this issue, see O Ben-Naftali (ed), International Humanitarian Law and International Human Rights Law (2011); J Klefner, 'Human Rights and International Humanitarian Law: General Issues', in: T Gill \& D Fleck (eds), The Handbook of the International Law of Military Operations (2010) 51-77; R Arnold, N Quénivet, International Humanitarian Law and Human Rights Law: Towards a New Merger in International Law (2008).
} 


\section{Framing the discussion}

There are a number of elements of an enquiry into the relationship between IHL and HRL and the application of the latter in armed conflict:

1. whether HRL conventions-for ease of discussion, the 1966 International Covenant on Civil and Political Rights (ICCPR), ${ }^{2}$ the 1984 Convention Against Torture $(C A T))^{3}$ and, given its frequent bellwether quality, the 1950 European Convention on Human Rights $(E C H R)^{4}$-apply extraterritorially, and, if so, in what circumstances and to what extent;

2. if some or all of these HRL conventions apply extra-territorially, whether they apply on their face in armed conflict, i.e. the issue of formal de jure application, including questions of derogation, requiring potentially both a convention-by-convention and a provision-by-provision analysis;

3. a subset of the preceding enquiry is usefully whether these conventions, and their individual provisions, are amenable to reasonable application in armed conflict, and, if so, whether or not they apply de jure, there are policy considerations that suggest their application as a matter of discretion;

4. if HRL conventions and provisions apply de jure in armed conflict, or ought to be applied as a matter of discretion, the relationship between IHL and HRL, requiring both a convention-by-convention and a provision-byprovision analysis, including the so-called lex specialis issue;

5. whether any conclusion emerging from the preceding analysis needs to be revisited as we move (as we must) beyond a review of conventional law to a review of customary international law $(C I L)$ standards of both IHL and HRL, including such questions as:

a) whether there are limits on the application of CIL, e.g. issues of erga omnes application, territorial application, self-executing CIL etc;

b) implications flowing from the jus cogens quality of a given CIL principle, e.g. the prohibition on torture;

2 International Covenant on Civil and Political Rights, 16 December 1966, 999 UNTS 171.

3 Convention against Torture and Other Cruel, Inhuman or Degrading Treatment or Punishment, 10 December 1984, 1465 UNTS 85.

4 Convention for the Protection of Human Rights and Fundamental Freedoms, 4 November 1950, 213 UNTS 222. 
c) the content of CIL rules in this area and the approach to determining this;

d) issues of potential normative uncertainty associated with the clarity of conventional rules but the potential relative vagueness of CIL rules;

e) the interaction between CIL and conventional international law, e.g. issues of supervening CIL and the relevance and application of CIL for purposes of IHL and HRL treaty interpretation;

6. the relevance of CIL principles of state responsibility $(S R)$ to these issues, notably those concerning the international legal responsibility that attaches to a state in consequence of the acts or omissions inter alia of those:

a) exercising governmental authority; or

b) acting on the instructions of, or under the direction or control of, a state,

wherever in the world such acts or omissions may take place.

There is, separately, also the issue of the responsibility that may attach to aid or assistance provided by one state to another. Both of these issues engage distinct questions of territorial application, interaction between the primary obligations of IHL and HRL, and potentially of other obligations of international law;

7. the relevance to this broader enquiry of principles of international criminal law (ICL), of both conventional and customary character, which mirror IHL and HRL standards; and

8. whether the provenance of obligations potentially applicable in situations of armed conflict-IHL, HRL, SR or ICL; conventional or customarymatters for admissibility, jurisdictional, procedural, interpretative, accountability, revision, or other reasons.

Separate from these lines of enquiry are questions of the application of national constitutional and legislative provisions extra-territorially and in armed conflict, and the relationship between such provisions and applicable IHL and HRL rules. These aspects are not addressed further in this paper, although it bears emphasis that the national laws of many states, particularly in the fundamental rights and 
criminal law fields, apply or are capable of being applied extra-territorially and in armed conflict. It also bears emphasis that courts in various jurisdictions have shown a sharp antipathy to perceived circumstances of the non-application of any (adequate) legal standards and safeguards, with the result that they have inclined towards the extension and application of internationally derived fundamental rights standards to situations of armed conflict notwithstanding questions about the provenance, content and formal application of the relevant international rules.

Also not addressed in this paper, but potentially important to the wider enquiry, are two further questions. The first is the relevance to the issues identified above of whether an armed conflict is an international armed conflict, a non-international armed conflict or a conflict having some hybrid character. ${ }^{5}$ This goes to questions of the potential application, perhaps even of a trumping nature, of the domestic law of the state in whose territory the armed conflict is taking place. The second question goes to the implications, if any, of the international legal basis for the use of force, notably, the terms of any authorisation by the UN Security Council under Chapter VII of the UN Charter, including any reference therein to compliance with IHL and/or HRL. This raises the questions of whether Security Council authorised action amounts to an armed conflict of the same nature, and engaging the same legal framework, as a more traditional armed conflict, and whether a Security Council authorisation could properly have the effect of requiring compliance with applicable HRL obligations directly, of elevating the bar of IHL standards by reference to an overlay of HRL standards, or of limiting the scope of otherwise applicable IHL rules and principles. This last element might take the form, for example, either explicitly or by reference to the purpose of the action, of imposing limits on targeting objectives, of requiring a broader appreciation of such principles as military necessity and proportionality, of requiring compliance with HRL-derived standards going beyond IHL relevant to detention, etc.

None of the preceding questions is abstract or academic in nature. Whether or not always in this precise form or detail, all have required and engaged operational attention from government legal advisers, both civilian and military. Amongst the significant challenges of operational advice in this area are that (a) few of these questions admit of clear or authoritative answers; (b) the variable geometry of applicable legal standards across allies engaged in a common endeav-

${ }^{5}$ For a recent discussion of this issue, see $\mathrm{E}$ Wilmshurst (ed), International Law and the Classification of Armed Conflicts (2012). 
our, or in shared or joint operations, pose significant additional de-confliction and inter-operability issues; (c) not all of these issues are readily amenable to definitive slower time strategic advice, as opposed to stressed, real-time operational advice; and (d) the complexities of these issues is by some margin not often adequately understood by courts, legislators and non-governmental commentators actively engaged on these issues from the perspective of their own competences and responsibilities.

For purposes of discussion, the remainder of this paper addresses core issues relevant only to questions 3 and 4 above.

\section{The systemic relationship between IHL and HRL}

Operating at a level of high generality, the currently controlling appreciation of the relationship between IHL and HRL is set out in the 2004 Wall Advisory Opinion of the International Court of Justice in the following terms:

the Court considers that the protection offered by human rights conventions does not cease in case of armed conflict, save through the effect of provisions for derogation of the kind to be found in Article 4 of the International Covenant on Civil and Political Rights. As regards the relationship between international humanitarian law and human rights law, there are thus three possible situations: some rights may be exclusively matters of international humanitarian law; others may be exclusively matters of human rights law; yet others may be matters of both these branches of international law. ${ }^{6}$

The focus of the Advisory Opinion was Israel's long-term belligerent occupation of the West Bank, presumptively engaging issues under both Hague Regulations law $^{7}$ and the Fourth Geneva Convention, ${ }^{8}$ the further question being whether obligations under the ICCPR also applied. While the ICJ went on to address the

\footnotetext{
${ }^{6}$ Legal Consequences of the Construction of a Wall in the Occupied Palestinian Territory, Advisory Opinion, ICJ Reports 2004 p 136, para 106.

7 See Hague Convention (II) with Respect to the Laws and Customs of War on Land and Annex, Regulations concerning the Laws and Customs of War on Land, 29 July 1899,187 CTS 429; and Hague Convention (IV) respecting the Laws and Customs of War on Land and Annex, Regulations concerning the Laws and Customs of War on Land, 18 October 1907, 205 CTS 277.

${ }^{8}$ Geneva Convention relative to the Protection of Civilian Persons in Time of War, 12 August 1949, 75 UNTS 287.
} 
extra-territorial application of the ICCPR, Israel's derogation thereunder, and the application of particular ICCPR provisions in the circumstances under review, it did not undertake any further analysis of the relationship between the applicable IHL rules and those of the ICCPR that it held to apply, simply commingling in its analysis various provisions from both strands.

Given the high level of generality of the Court's statement on the relationship between IHL and HRL, and the absence of any subsequent analysis of the interaction of these two bodies of law at an operational level, there is little useful guidance to be had from this opinion on the detail of the relationship between IHL and HRL apart from the Court's bottom line conclusion that certain specified provisions of the ICCPR applied in the circumstances of Israel's (then) 37 year belligerent occupation of the West Bank.

There is, of course, other jurisprudence, both prior and subsequent to the Wall Advisory Opinion, that addresses these matters. Of greater assistance to the analytical enquiry is the narrower observation in the ICJ's 1996 Advisory Opinion on the Threat or Use of Nuclear Weapons in the following terms:

The Court observes that the protection of the International Covenant of Civil and Political Rights does not cease in times of war, except by operation of Article 4 of the Covenant whereby certain provisions may be derogated from in a time of national emergency. Respect for the right to life is not, however, such a provision. In principle, the right not arbitrarily to be deprived of one's life applies also in hostilities. The test of what is an arbitrary deprivation of life, however, then falls to be determined by the applicable lex specialis, namely, the law applicable in armed conflict which is designed to regulate the conduct of hostilities. Thus whether a particular loss of life, through the use of a certain weapon in warfare, is to be considered an arbitrary deprivation of life contrary to Article 6 of the Covenant, can only be decided by reference to the law applicable in armed conflict and not deduced from the terms of the Covenant itself. $^{9}$

The general propositions that follow from this observation are that:

${ }^{9}$ Legality of the Threat or Use of Nuclear Weapons, Advisory Opinion, ICJ Reports $1996 \mathrm{p} 226$, para 25. 
1. ICCPR provisions (and by extension potentially also those of other applicable HRL conventions) apply in armed conflict save insofar as they have properly been the subject of derogations;

2. the relevant applicable ICCPR (or other HRL) provision operates as an enquiry gateway, with an implicit renvoi, once the gateway has been passed, to the lex specialis governing these matters;

3. IHL is the lex specialis relevant to armed conflict;

4. the substantive enquiry turns on the lex specialis alone, not on the terms of the applicable ICCPR (or other HRL) provision; but that

5. a violation of the relevant IHL rule will ipso jure also constitute a violation of the relevant Covenant (or other HRL) provision.

This analysis does not address other important threshold questions, such as those of the extra-territorial application of ICCPR (and/or other HRL) provisions and issues of jurisdiction and control, and a more nuanced enquiry would be necessary in circumstances in which there was either no relevant applicable IHL rule or the relevant applicable IHL rule was somehow substantively inadequate. But, these issues apart, the conclusions flowing from the Nuclear Weapons Advisory Opinion are both more considered and more useful, and better attuned to the complexity of the issues, than those flowing from the more recent Wall Advisory Opinion.

One of the challenges of the present debate about the relationship between IHL and HRL is that it is the broad brush of the Wall Advisory Opinion that is usually reflexively quoted and relied upon as the starting point for any judicial or other analysis of these issues, usually to the detriment of a more considered enquiry. So, for example, it was the Wall statement that was the starting point of the analysis of the European Court of Human Rights in its Al-Skeini judgment of 7 July $2011,{ }^{10}$ which thereafter turned on an appreciation of belligerent occupation in Iraq, although without at any point ever engaging with the more detailed issue of the operational relationship of relevant principles of IHL and Article 2 of the ECHR. ${ }^{11}$ While there may be a case for saying that the Court's bottom line-that the UK's investigative responsibilities had not adequately been acquitted ${ }^{12}$-was

\footnotetext{
${ }^{10}$ Al-Skeini and Others $v$ UK, [2011] ECHR 55721/07, para 90.

${ }^{11}$ Ibid, paras 143-8.

${ }^{12}$ Ibid, paras 168-77.
} 
correct, the absence of any analysis of applicable IHL obligations, and of the relationship between those obligations and those of Article 2 of the ECHR, is a cause for disquiet.

Another challenge of the present debate is that discussion of the application of ICCPR or other HRL standards in armed conflict is proceeding on the basis that it is a lock-stock-and-barrel exercise, i.e. the discussion invariably addresses only the generic application of the ICCPR or other HRL conventions in armed conflict, rather than proceeding by way of a provision-specific analysis. If a discussion of these issues is to be useful, however, it must focus on specifics. To this end, a helpful initial enquiry is simply whether particular HRL provisions are in common sense terms amenable to reasonable application in armed conflict. As an enquiry of this nature side-steps questions of the de jure application of HRL, it allows a detached evaluation of whether, even if such principles do not apply de jure, there may be broad support for their application as a matter of discretion. This aspect is addressed further below.

Consideration is also required at a level of detail of the potential range of the relationship between IHL and HRL provisions. To unpack this, it is useful to proceed by way of an assumption that HRL provisions are applicable extra-territorially and in armed conflict and move from there to address a number of scenarios, including:

1. circumstances in which there are relevant and applicable IHL provisions addressing the circumstances at issue;

2. circumstances in which there are relevant IHL provisions that would address the circumstances at issue but that, for one reason or another, are not applicable;

3. circumstances in which there are relevant and applicable IHL provisions but there is a reasonable basis for concluding that, for whatever reason, they are insufficiently developed for purposes of appropriate contemporary application;

4. circumstances in which there are relevant and applicable IHL provisions but they are materially at odds with relevant applicable HRL provisions;

5. circumstances in which there is no relevant IHL provision; 
6. circumstances in which there is substantive overlap between relevant and applicable IHL and HRL provisions but the relevant HRL would introduce additional elements of process or remedy.

The purpose of this enquiry is to require a more focused analysis of how IHL and HRL provisions might interact in circumstances in which both are applicable. Various possibilities are apparent, on the assumption that IHL is the lex specialis and therefore the body of law of presumptive and principal application. Thus, by reference to the preceding scenarios, HRL might:

1. simply act as a gateway for the application of the relevant and applicable IHL provision by way of an implicit renvoi;

2. operate to give effect to a relevant but otherwise inapplicable provision of IHL;

3. inform the interpretation of the substantive IHL obligation, possibly including by way of supplementing or completing it for purposes of appropriate contemporary application;

4. prevail over an inconsistent IHL provision;

5. fill in the gap in circumstances in which there is no relevant IHL provision;

6. augment the relevant and applicable IHL obligation by way of HRL procedural and accountability mechanisms.

Against this background, what is clear is that governments and their legal advisers should be more prepared to engage in a deeper public discussion of these issues than has hitherto been the case. For understandable reasons-to do with operational pressures, the complexity of the issues, anxieties around litigation, entrenched positions around issues of extra-territoriality, jurisdiction and control, etc-the public debate about the relationship between IHL and HRL in armed conflict has so far attracted less public governmental participation than it warrants. Closer governmental engagement would facilitate a more informed debate and would assist in shaping the development of the law in this area to sensible ends. 


\section{Are core HRL provisions amenable to reasonable application in armed conflict?}

For ease of discussion, this section takes as its focus provisions of the ICCPR. The initial question is whether these provisions are amenable to reasonable application in armed conflict. This enquiry is intended as a practical tool to evaluate the possible application of ICCPR provisions in particular armed conflict situations.

For purposes of a considered analysis, it is necessary to parse armed conflict action into its constituent parts. A number of sub-divisions may be possible. One possible matrix might be:

1. conduct of battlefield operations;

2. battlefield operational control of territory;

3. battlefield capture, i.e. temporary detention away from fixed or dedicated detention facilities;

4. tactical (battlefield) questioning;

5. elongated operational military control of territory;

6. detention;

7. interrogation;

8. prosecution;

9. investigation of battlefield incidents;

10. compensation for civilian damage as a result of battlefield incidents;

11. extended strategic military control of territory short of belligerent occupation;

12. belligerent occupation, i.e. territory under military occupation authority.

The purpose of a matrix of this kind is to assess the types of situations in which it may be reasonable, or unreasonable, to regard HRL provisions as amenable to application, whether for purposes of informing the interpretation of relevant and applicable IHL provisions or to some other end. 
Within this matrix, it is useful to consider the potential for reasonable application of each substantive provision of the ICCPR, including the extent to which a given ICCPR provision finds corresponding expression in some provision of IHL.

For purposes of the present discussion, a review against the preceding matrix of a number of ICCPR provisions illustrates the trend. So, for example, at one end of the spectrum, looking at Article 7-the prohibition on torture or cruel, inhuman or degrading treatment or punishment-it is unlikely to be controversial to conclude that this is amenable to reasonable application in all situations of armed conflict. Further, it is readily apparent that the principle in Article 7 finds corresponding expression in all the key IHL conventions.

In contrast, at the other end of the spectrum, taking Article 25, ICCPR-the right to take part in the conduct of public affairs and to participate in periodic elections-it is difficult to sensibly contend that this is amenable to reasonable application in armed conflict other than perhaps under matrix heading (12), circumstances in which the territory in question is under military occupation authority, i.e. the law of belligerent occupation applies. There may possibly be argument about whether this provision could be capable of reasonable application in circumstances of extended strategic military control of territory short of belligerent occupation (heading (11)), perhaps because an election had previously been scheduled, but even this is likely to be controversial. It follows from this that it is likely to be largely uncontroversial to conclude that Article 25, ICCPR is not amenable to reasonable application in virtually all circumstances of armed conflict.

Unsurprisingly, most of the provisions of the ICCPR fall between these two extremes, although with significant doubt arising about the reasonable application of even the non-derogable ICCPR rights the closer one gets to the battlefield. So, for example, it is not clear that Article 11 (imprisonment for contractual obligations), Article 15 (non-retroactivity of criminal offences) and Article 18 (freedom of thought, conscience and religion) could have any meaningful application to the conduct of battlefield operations, battlefield operational control of territory, battlefield capture, tactical (battlefield) questioning, elongated operational military control of territory, and perhaps other scenarios. And, as regards most of the ICCPR derogable rights, significant questions arise about their potential for reasonable application in most of the scenarios apart from belligerent occupation and perhaps, in respect of some provisions, circumstances of detention. And, as regards Article 6 (the right to life and the prohibition of arbitrary deprivation of life), the ICJ Nuclear Weapons Advisory Opinion concluded that 'whether a partic- 
ular loss of life ... is to be considered an arbitrary deprivation of life contrary to Article 6 of the Covenant, can only be decided by reference to the law applicable in armed conflict and not deduced from the terms of the Covenant itself.' ${ }^{13}$

The upshot of a review of this kind is that it is apparent that not all provisions of the ICCPR are amenable to reasonable application in all situations of armed conflict and, even if they are in some circumstances, very few are amenable to reasonable application in situations of armed conflict across the board. As a rule of thumb, the closer one gets to the battlefield the less amenable to reasonable application are most provisions of the ICCPR.

An article-by-article review also discloses that in many cases ICCPR provisions find detailed corresponding expression in some form in IHL. So, for example, Articles 49-57 of the Third Geneva Convention contain detailed provisions concerning the labour of prisoners of war, provisions that might be said to occupy the same space as Article 8 of the ICCPR, concerned with the prohibition of slavery and forced or compulsory labour. In similar vein, Article 14 of the Third Geneva Convention and Article 80 of the Fourth Geneva Convention, inter alia affirming the civil capacity of prisoners of war and internees respectively, find some correspondence in Article 16, ICCPR, containing the right to recognition as a person before the law.

In contrast, in other cases, IHL provisions either expressly or implicitly cut across ICCPR principles such as to raise questions about the scope of application of the latter. So, for example, the terms of Article 76 of the Third Geneva Convention, which inter alia permits the censoring of correspondence addressed to prisoners of war, an issue which might be said to engage the application of Article 17 (interference with privacy) and Article 19 (freedom of expression) of the ICCPR, raises questions about the reasonable application of the ICCPR in such circumstances.

A number of questions and issues follow from the preceding. The first is whether a deeper analysis by courts and commentators would not be appropriate on the question of whether derogations are properly required in circumstances in which an armed conflict is taking place outside of the territory of the state. While there is undoubtedly an argument to the effect that the explicit latitude to derogate in times of public emergency implies the application of non-derogable and non-derogated from HRL treaty provisions in times of armed conflict, there is also a basis for saying that, given that IHL is the lex specialis, and that all of HRL is self-evidently not readily amenable to reasonable application in armed

${ }^{13}$ See above, $\mathrm{n} 9$. 
conflict, it is unreasonable to conclude that there is a presumption in favour of the application of HRL treaty provisions absent derogation.

It may not ultimately be necessary to choose between these two propositions, however, as they may be reconcilable through a pragmatic enquiry that would turn simply on whether the HRL rule operated as a gateway, with an implicit renvoi to the relevant rule of IHL. If so, questions of derogation and the substantive application of HRL would become considerably less challenging.

A second issue is that the sharp end of the IHL-HRL relationship arises in circumstances in which rules derived from each strand address the same issues but are substantively at odds. While, in practice, circumstances in which the substantive content of overlapping IHL and HRL provisions will be materially divergent are likely to be relatively limited, where there are such material divergences it will be important that the law develops an appropriate methodology of hierarchy, presumption, reconciliation and interpretation.

A third issue is that some of the challenges around the debate about the IHL-HRL relationship arise from courts or bodies of limited jurisdiction being seised of questions which transcend not simply their jurisdictional competence but also their material competence. The result is often that, even as they stretch their jurisdictional competence, they fail to properly engage with the law relevant to the merits of the case.

A fourth question is whether, and if so what, significance attaches to the provenance of a given legal principle. While provenance may be relevant to issues of process, remedies etc, it may not ultimately be critically determinative of the existence of a legal obligation. The United Kingdom, for example, is party to the four Geneva Conventions, Additional Protocols I and II, the ICCPR, ECHR and the CAT, and the Statute of the International Criminal Court, and also takes a reasonably expansive view of CIL in this area, all these principles being justiciable before UK courts. In any given circumstance, therefore, although questions of process, remedies and related considerations may be relevant, there may also be a practical question of whether it ultimately makes any real difference from where a principle is derived.

The final question flowing from the preceding is, in the event that a given HRL rule is amenable to reasonable application in armed conflict, but may not be, or be questionably, applicable de jure, whether there are policy considerations that would in any event favour its application as a matter of discretion. The short answer to this is likely to be that such considerations do indeed operate and that many states frequently give effect on a discretionary basis to principles that do not have de jure application. It would further be said, however, that discretion is 
discretion, and that it is important to preserve the flexibility and perhaps other considerations that come with discretion.

Such considerations are undoubtedly important but there may be a risk here of elevating form over substance to no useful effect. As noted in opening, courts have shown an antipathy towards situations of perceived non-application of adequate legal standards, with the result that they have inclined towards the application of internationally derived standards without undue regard to questions of provenance, content and formal application. Given this, it may be sensible for states both to be more forward leaning and transparent about the application of HRL standards on a discretionary basis and ultimately to consider whether there is a mechanism to give effect to such standards de jure.

Four conclusions are suggested by the preceding review. First, the risk of real normative discordance between IHL and HRL is probably overstated. Second, the anxiety in this area is largely driven by warranted concern over the methodological shortcomings of courts and other bodies seised of these issues, particularly on the human rights side of the equation. Third, there is a reasonable and proper space within IHL for reference to HRL standards. Fourth, governments and their legal advisers ought to encourage and engage more fully in wider and better informed public debate on these issues.

\section{Assuming that HRL provisions apply in armed conflict, what is the relationship between relevant IHL and HRL provisions?}

Elements of an enquiry into the operational relationship between IHL and HRL rules have been addressed above. The observations by the ICJ in its Nuclear Weapons and Wall Advisory Opinions, to which can be added the Court's 2005 observations in the Armed Activities (DRC v Uganda) case, ${ }^{14}$ are the starting point. As noted, the view preferred in this paper is that the Court's analysis in the Nuclear Weapons Advisory Opinion engages with this debate at a greater level of nuance appropriate to the complexity of the issues even if both the ICJ and other courts and bodies have subsequently inclined towards an approach that has avoided analysis of the operational interaction between IHL and HRL.

${ }^{14}$ Armed Activities on the Territory of the Congo (Democratic Republic of the Congo $v$ Uganda), Judgment, ICJ Reports 2005 p 168, paras 215-21. 
One possible explanation for the absence of such analysis may be that the tribunals in these cases have not regarded the relevant IHL and HRL principles as in conflict, a lex specialis or other de-confliction analysis only being necessary in circumstances in which there are conflicting rules. This explanation raises the question of whether a different analysis may not properly be required, addressing the question of whether a lex specialis does not displace the lex generalis more comprehensively.

There is some support for the proposition that a lex specialis occupies the legal space to the exclusion of general rules, i.e. that it operates as a choice of law principle rather than simply as a principle of interpretation. Article 55 of the International Law Commission's articles on state responsibility, for example, provides that the SR principles 'do not apply where and to the extent that ... [issues of responsibility] are governed by other rules of international law.' ${ }^{15}$ The International Law Commission's 2006 Conclusions of the work of the Study Group of the Fragmentation of International Law: Difficulties arising from the Diversification and Expansion of International Law also contemplates the possibility that the function of lex specialis may be to set aside the general law. ${ }^{16}$ ILC conclusion (8), for example, provides 'that special law may be used to apply, clarify, update or modify as well as set aside general law. ${ }^{, 17}$ While there is some force to this argument, however, this issue may in practice hinge more on appreciations of competence, jurisdiction and admissibility than on a compelling view of international law as a system of discrete, non-interacting islands of substantive rules. Before a court of general jurisdiction, it would be unlikely to be persuasive to contend that only one strand of law relevant to an issue should be addressed.

Beyond this issue, there is a range of other questions that arise for consideration under this head. One is whether it is correct at all to think of IHL as the lex specialis, rather than considering both IHL and HRL as special bodies of law that properly apply in situations in which the rights of persons are engaged. While the Nuclear Weapons Advisory Opinion proceeded on the basis that IHL was the lex specialis, it is not clear from subsequent jurisprudence that this appreciation subsists.

Separately from this issue, there would be advantage in greater clarity about the interaction between IHL and HRL in particular situations of armed conflict. As suggested above, this might be usefully analysed around scenarios that would

\footnotetext{
${ }^{15}$ UNGA Res 56/83, 12 December 2001, Annex.

${ }^{16}$ Report of the International Law Commission, 58th session (2006), UN Doc A/61/10, p 407-23.

${ }^{17}$ Ibid, p 409.
} 
facilitate a better understanding of how such interaction might actually unfold in practice. As mentioned, this could take a number of forms:

1. HRL might act as a gateway for the application of IHL by way of renvoi;

2. HRL might give effect to a relevant but otherwise inapplicable provision of IHL;

3. HRL might inform the interpretation of IHL, including possibly by supplementing or completing the IHL rule;

4. HRL might prevail over inconsistent IHL;

5. HRL might fill in the gaps in circumstances in which there is no relevant IHL provision;

6. HRL might augment IHL through HRL procedural and accountability mechanisms.

Clarity would also be aided by a provision-by-provision analysis, by reference to a matrix of conduct, rather than the more stratospheric analysis that has tended to take place to this point. A more nuanced analysis would facilitate the development of a methodological framework more appropriate to the complexity of the issues.

\section{Conclusion}

The issues of the application of HRL to armed conflict, whether de jure or on a discretionary basis, and of the interaction between IHL and HRL, are both of operational importance and have wider systemic implications, including for the values at the heart of our democracies. The debate to this point, however, has too often been characterised by a high level of generality, a lack of judicial rigour, a failure by those in government to engage actively in public discussion, overly expansive claims on the part of non-governmental commentators, and anxiety on the part of the military that these developments are hampering the flexibility to act effectively to keep society safe. In reality, however, many of the issues are likely to be readily and reasonably addressed if those with responsibilities in these areas engage with the issues at a greater level of nuance and have a better appreciation of their wider implications. 


\title{
Minding the Gap between Scholarly Discourse and State Practice in International Humanitarian Law
}

\author{
Book Review \\ Wilmshurst, Elizabeth (ed), International Law and the Classification of Conflicts \\ (Oxford University Press, 2012). 568 pages; $£ 85$ (hardback). \\ Sivakumaran, Sandesh, The Law of Non-International Armed Conflict (Oxford \\ University Press, 2012). 696 pages; $£ 95$ (hardback).
}

Noam Zamir*

One wishes that the fate of war victims would be as promising as that of the scholarship on the law that ostensibly protects them, international humanitarian law $(I H L)$. The two excellent books under review contribute significantly to the already flourishing academic IHL discourse ${ }^{1}$ in a manner that engages rather than discards that scholarship's 'nemesis': state practice. The need to enrich the IHL discourse with state practice has already been suggested by Adam Roberts:

The laws of war are strange not only in their subject matter, which to many people seems a contradiction in terms, but also in their methodology. There is little tradition of disciplined and reasoned assessment of how the laws of war have operated in practice ... In short, the study of law needs to be integrated with the study of history: if not, it is inadequate. ${ }^{2}$

\footnotetext{
PhD Candidate, University of Cambridge.

1 To name just a few books published in recent years: E Benvenisti, The International Law of Occupation (2 $2^{\text {nd }}$ edn, 2012); W H Boothby, The Law of Targeting (2012); O Ben-Naftali (ed), International Humanitarian Law and International Human Rights Law (2011); C Ford \& A Cohen (eds), Rethinking the Law of Armed Conflict in an Age of Terrorism (2011); E Crawford, The Treatment of Combatants and Insurgents under the Law of Armed Conflict (2010); A Cullen, The Concept of Non-International Armed Conflict in International Humanitarian Law (2010); N Higgins, Regulating the Use of Force in Wars of National Liberation: The Need for a New Regime (2010); N Lubell, Extraterritorial Use of Force Against Non-State Actors (2010).

2 A Roberts, 'Land Warfare: From Hague to Nuremberg', in M Howard, G J Andreopoulous \& M R Shulman (eds), The Laws of War: Constraints on Warfare in the Western World (1994) 117.
}

Copyright $\odot$ the Author(s).

This work is licensed under a Creative Commons Attribution-NonCommercial-NoDerivs 3.0 License. 
Indeed, both books take an even greater step in bridging the gap between discourse and practice by taking account of the positions of states and the increasingly important positions of armed groups involved in the various armed conflicts the authors discuss.

Such contribution is in and of itself a good enough reason for any IHL scholar to read these books. There are more.

The Law of Non-International Armed Conflict is only the second recent book fully dedicated to examining applicable law in non-international armed conflicts (NIACs). ${ }^{3}$ International Law and the Classification of Conflicts is the only book, so far, that offers an in-depth examination of conflict classification under IHL.

The Law of Non-International Armed Conflict offers a critical examination of the content, application and enforcement of the law of NIAC. Incorporating the views of parties to armed conflicts, both states as well as non-state armed groups, strengthens the analysis.

The book is divided into three sections. The first section examines how NIACs have been regulated by international law. The great merit of this section is the novel approach it takes in examining less traditional sources of the law of NIAC such as instructions, codes of conduct, internal regulations and domestic legislation. The second section focuses on the substantive law of NIAC. It examines when a given NIAC can be said to exist; discusses the distinction between NIACs and international armed conflicts (IACs); the notion of transnational armed conflicts; and examines the scope of application of the law, the substantive rules that apply with regard to the protection of civilians and persons hors de combat and with regard to the conduct of hostilities. It concludes by examining the implementation and enforcement of the law of NIAC. The third section advances different proposals relative to the development of the law of NIAC in terms of substance, implementation, enforcement, and formation.

This is a rich and lengthy book (696 pages, including index and bibliography). It is also courageous: Sivakumaran does not shy away from discussing some of the most debatable issues in IHL such as the classification of transnational armed conflicts and the internationalisation of NIACs due to involvement of foreign states. Because the richness of sources and variety of arguments do not allow for a comprehensive discussion, I will address only the latter issue, and further relate it to the second book under review.

The concept of internationalisation has been defined as 'transformation of a prima facie NIAC into an IAC, thereby applying to this conflict the more compre-

3 L Moir, The Law of Internal Armed Conflict (2002). 
hensive IAC legal regime.' ${ }^{4}$ Sivakumaran summarises the leading tests for internationalisation in relation to indirect military intervention, the 'effective control' and the 'overall control' tests established by the ICJ and ICTY respectively, ${ }^{5}$ rejects them, ${ }^{6}$ and advances a novel argument as to what kind of relations the foreign state needs to have with the non-state group in order to internationalise the NIAC between the non-state group and the territorial state. He proposes that it is the 'notion of a proxy that transforms what seems to be a conflict that is fought between a state and an armed group into a conflict that is actually being fought between states.7 This proposition, while intriguing, is not devoid of difficulties. I shall sketch three of them.

First, while Sivakumaran provides important indicators for proxy relations between the foreign state and the non-state group that would generate the internationalisation of the armed conflict between the territorial state and the non-state group (e.g. the sharing of forces and financing, and the shared military objectives and strategies of the outside state and the armed group), these indicators do not really differentiate between close allies and a proxy (i.e. close allies can and in practice do share forces and provide financial support to each other). More importantly, these indications cannot provide a substitute for a clear test. Both the 'effective control' and the 'overall control' tests deserve skepticism but they do provide much needed clarity in an otherwise confusing arena.

Second, the proxy approach shares with the 'effective control' and the 'overall control' tests the 'real time' problem: the list of indications for proxy relation can usually be assessed only ex post a given armed conflict. This is particularly troubling because the actors in the battlefield cannot be expected to obey the law of IAC if they still believe they are engaged in a NIAC.

Third, although Sivakumaran successfully combines state practice and opinions of the parties to armed conflicts in most parts of the book, he does not state any relevant state practice in the section on internationalisation due to indirect military intervention. ${ }^{8}$ This lacuna is partially filled in International Law and the Classification of Conflicts.

\footnotetext{
${ }^{4}$ On internationalisation in general, see M Milanović \& V Hadži-Vidanović, 'A Taxonomy of Armed Conflict', in N White \& C Henderson (eds), Research Handbook on International Conflict and Security Law (2013) (forthcoming).

${ }^{5}$ See Military and Paramilitary Activities in and against Nicaragua (Nicaragua v US), ICJ Reports 1986 p 14, 54-5; Prosecutor v Tadić, Appeal Judgment, Case IT-94-1-A, 15 July 1999, para 130-7 (Tadić).

6 S Sivakumaran, The Law of Non-International Armed Conflict (2012) 225-8.

7 Ibid, 227.

${ }^{8}$ Ibid, 225-8 (this section is titled 'State control over an armed group').
} 
International Law and the Classification of Conflicts comprises a collection of chapters divided into three sections: the first deals with basic IHL concepts and legal questions in general and with conflict classifications in particular; the second examines armed conflicts that involve complex legal issues pertaining to classification of armed conflicts; the third synthesizes the findings of the different authors of the second section with the analytical insights contained in the first section.

The editor's choice to initiate readers into the subject matter through Steven Haines' The Nature of War and the Character of Contemporary Armed Conflict is commendable. By intentionally excluding the topic of the law that regulates hostilities from the scope of the discussion, Haines introduces us to notable literature from disciplines such as military history and war studies. Such focus is particularly warranted given that every legal text derives meaning from its context and that much IHL scholarship does not otherwise benefit from an interdisciplinary approach to the study of war. Dapo Akande's chapter on the Classification of Armed Conflicts: Relevant Legal Concepts examines the distinction between IACs and NIACs and a variety of derivative legal questions and advances novel arguments regarding internationalisation of NIACs and the classification of transnational armed conflicts between states and non-state groups as IAC under particular circumstances. Jelena Pejic's Conflict Classification and the Law Applicable to Detention and the Use of Force focuses on the rules governing the deprivation of liberty of persons, the transfer of detainees and the use of force under the law applicable in IAC and NIACs. In addition to an analysis both concise and comprehensive of complicated questions relative to targeting and 'direct participation' in hostilities, this chapter further canvasses the vast literature on the relationship between IHL and international human rights law $(I H R L)$ in the context of internment and the use of force in NIACs. Pejic persuasively highlights the shortcomings of solely relying on IHRL as a legal basis for internment in NIACs, a reliance that ignores the critical differences between war and peace and the legal and practical limits of applicability of IHRL to non-state groups in NIACs.

The second section revolves around case-studies of hostilities that took place in Northern Ireland (1968-1998); The Democratic Republic of the Congo (1993-2010); Colombia (the 1960s onwards); Afghanistan (2001-2010); Gaza (2000-2011); South Ossetia (2008); Iraq (2003 onwards); and Lebanon (2006). In addition, the conflict against Al-Qaeda is also thoroughly analysed. There is also a brief description and analysis of the recent armed conflict in Libya (2011) and 
the fighting against organised cartels in Mexico. ${ }^{9}$ The second section contains a notable contribution by Michael N. Schmitt that examines the classification of future battle-fields, including cyber warfare, transnational terrorism and complex battle-spaces.

Each case-study is structured in a similar format: it provides a short historical review of the relevant conflict; an identification of the different actors and their positions regarding the conflict's classification; and a substantive analysis of the classification, which includes an assessment of the impact of the conflict classification on two pertinent issues: application of force and detention of individuals in hostilities.

Understandably, the book could not cover all modern armed conflicts that involved challenging conflict classification questions, but it does an excellent job in raising some of the most interesting and pressing legal questions (e.g. conflict classifications in cases of direct and indirect foreign intervention, classification of NIACs with changing intensity, classification of transnational armed conflict). The concise factual explanation of these conflicts is most helpful and interesting and the substantive analysis of issues relative to conflict classification is excellent. Most notably, the authors include the otherwise neglected area in scholarly writing on classification of armed conflicts, that is the views of the different actors in the conflict relative to its proper classification. It is plausible that such views are hardly ever discussed partly because, with the exception of recognition of belligerency, ${ }^{10}$ conflict classification is not contingent on the views of the actors and partly because of practical difficulties in ascertaining these positions. ${ }^{11}$ These positions are, however, of great importance, not least because they disclose the wide gap between legal discourse and practice. To the extent that the discourse minds the gap, as I think it should, a study of the positions of the relevant actors is a good starting point. In this regard, this book is not only refreshing but further makes an invaluable contribution to the IHL discourse.

The third section summarises the findings of the different case studies from the second section in light of the discussions presented in the first section. It highlights the difficulties different authors encountered studying the different cases, and draws conclusions relative to both the consequences of conflict

\footnotetext{
${ }^{9}$ E Wilmshurst (ed), International Law and the Classification of Conflicts (2012), chapter 2 and chapter 15 .

${ }^{10}$ On the doctrine of belligerency and its applicability in contemporary international law, see D Akande, 'Classification of Armed Conflicts: Relevant Legal Concepts', in Wilmshurst (ed), above n 9, 49-50 and I Scobbie, 'Gaza', ibid, 301-5; See also Sivakumaran, above n 6, 9-20.

${ }^{11}$ On these practical difficulties, see Wilmshurst (ed), above n 9, 479.
} 
classifications and the law.

It is interesting to note a potential complementarity between the two books under review: The Law of Non-International Armed Conflict focuses on the concept of internationalisation but does not include a study of the positions of the relative actors on this issue, while the case-studies in International Law and the Classification of Conflicts examine these positions in practice, but do not develop the concept of internationalisation in the light of this practice, settling instead for either the effective control or the overall control tests. ${ }^{12}$

This potential complementarity should be construed as an invitation for future scholarship. Given that conflicts that have been considered internationalised by tribunals, scholars, IGOs and NGOs have rarely been conceived as such by their participants, future scholarship may well narrow the gap between discourse and practice. ${ }^{13}$ Three further points are worth making in this context.

First, the notion of internationalisation generated much judicial and academic excitement. Alas, it has failed to elicit a similar response from states and other relevant actors. This observation is exacerbated by the fact that, unlike other IHL concepts that states involved in armed conflicts also tend to refrain from acknowledging, ${ }^{14}$ 'internationalisation' does not have any clear treaty or customary law basis. This may undermine its validity as legal doctrine in international law.

Second, even if the notion of internationalisation can be explained as an interpretation of treaty law, ${ }^{15}$ it is still questionable whether it is wise to

${ }^{12}$ Even when some scholars offered different tests for internationalisation, they did not try to ground their suggestions in state practice. See Akande above n 10, 57-62 and F Szesnat \& A R Bird, 'Colombia', in Wilmshurst (ed), above n 9, 223-4.

${ }^{13}$ For example, the ICTY in the Tadic case decided that the armed conflict in Bosnia and Herzegovina between the Bosnian Serbs and the central authorities of Bosnia and Herzegovina was internationalised and therefore classified it as IAC (Tadić, Case IT-94-1-A, 15 July 1999, para 162). The parties to the conflict at that time, however, perceived it as NIAC (see Prosecutor $v$ Tadić, Trial Judgment, Case IT-94-1-T, 7 May 1997, para 583). A more recent example is the armed conflict in Libya (2011). In Libya, the non-state group (NTC) that fought against the Government (led by Gaddafi) was assisted by foreign states. The NTC classified the conflict as NIAC. Similarly, Gaddafi, despite the fact that he accused the NTC as being comprised of foreign agents, did not classify the conflict as IAC. Nevertheless, some scholars argued that this conflict was internationalised. See, for example, K A Johnston, 'Transformations of Conflict Status in Libya' (2012) 17 Journal of Conflict \& Security Law 81. Nevertheless, it should be stressed that classification of conflicts by the belligerent parties should not be accepted uncritically. See I Scobbie, 'Lebanon' in Wilmshurst, (ed) above n 9, 400-2.

${ }^{14}$ For example, states are often reluctant to acknowledge situations of internal violence as NIACs. See Wilmshurst (ed), above n 9, 479.

${ }^{15}$ The most convincing explanation would be that at the moment that a non-state group is 
interpret the Geneva Conventions without trying to ascertain the position of states to such an important issue. When states needed to express their opinion on a related notion-internationalisation in cases of direct military intervention-they strongly rejected it. They argued that if this notion would become part of international law;

... then as soon as a foreign State sent its troops over the border to help the rebels, thereby trespassing to begin with on the territorial rights of the neighbouring State, the State which suffered such aggression would have to treat its own rebels as prisoners of war and its local population as that of an occupied territory. ... No government could accept that. ${ }^{16}$

Granted, this position is no longer dominant. Nevertheless, it indicates that the suggestion that a conflict should be considered international just because an outside state assumed a relationship of control or co-ordination with the rebels may not be accepted by governments.

Third, internationalisation has a direct impact on the applicable law (e.g. whether the members of the non-state group may be entitled to POW status). The fact that the notion of internationalisation has rarely been assimilated by belligerent parties means that, at least when it comes to internationalisation, IHL remains a theoretical concept with no bearing on the fighting forces. It is, of course, possible to dismiss this fact and argue that states that are involved in these armed conflicts do not acknowledge internationalisation due to political reasons and that the impact of internationalisation should be assessed ex post a given armed conflict via international criminal law. It is equally possible and, to the extent that we would like IHL to impact the behaviour of actors, perhaps even desirable, to develop the concept of internationalisation in a manner that will be accepted and implemented by states during armed conflicts.

The two books under review are an excellent contribution to IHL scholarship, not least because both, in focusing on relevant state practice, highlight the need to bridge word and deed, discourse and practice. In so doing they have paved a

controlled by a foreign state then the non-state group is just an organ of the foreign state and not an independent actor. Therefore the armed conflict between the territorial state and the non-state group should be classified as IAC according to Common Article 2 of the Geneva Conventions that stipulates that conflicts between two or more states are international.

${ }^{16}$ ICRC, 'Conference of Government Experts on the Reaffirmation and Development of International Humanitarian Law Applicable in Armed Conflicts, 24 May-12 June 1971: Report on the Work of the Conference' (1971) 51, para 301(1) (emphasis added). 
road yet to be taken towards the development of a concept of internationalisation that converses with and therefore carries greater weight over state practice. 